\title{
Lilac Cultivar Name Registration 2003
}

\author{
Freek Vrugtman ${ }^{1}$ \\ Royal Botanical Gardens, Box 399, Hamilton, Ontario L8N 3H8, Canada
}

Commencing with Lilac Registrations 1995 standard portfolios are being established in accordance with Division V: Nomenclatural Standards, of the International Code of Nomenclature for Cultivated Plants, Seventh Edition (ICNCP-2004).

Previous registration lists of Syringa cultivar names appeared in AABGA Bulletin [13(4):105-110; 14(3):95; 15(3):71-72; 16(4):131-132; 17(3):67-69; 18(3):87]; HortScience [23(3):458; 24(3):435-436; 25(6):618; 26(5):476-477; 29(9):972; 31(3):327-328; 32(4):587588; 33(4):588-589; 34(4):600; 35(4):549; 36(5):836; 37(7):1145; 38(6):1301.

Syringa L. 'Spokane' (S. vulgaris $\times$ S. $\times$ hyacinthiflora) was registered 31 Dec. 2003, by M.L. Peterschick, 37307 Old SR 195, Rosalia, WA 99170, and R. Ballreich, P.O. Box 1804, Idyllwild, CA 92549. The original plant, the ortet (\#3-203), originated from the controlled cross $S$. vulgaris 'Tita' $\times$ S. $\times$ hyacinthiflora 'Mary Short' made by R. Ballreich, and selected in 1995. In July 1999 members of the Spokane Lilac Society chose \#3-203 for introduction, naming it for the city of Spokane, Wash. Initial vegetative propagation took place in 1998; the preferred methods of propagation are through softwood cuttings and tissue culture. Plants have flowered in the third year after propagation. Initial distribution of the clone took place in 2000; initial propagation by tissue culture in 2003 at Briggs Nursery, Olympia, Wash. The cultivar name 'Spokane' was first published in 2002. Three-year-old shrubs are about $1.5 \mathrm{~m}$ tall. Thyrses 15 to $20 \mathrm{~cm}$ long and 10 to $12 \mathrm{~cm}$ in diameter; florets staminode double, $1.5 \mathrm{~cm}$ in diameter. Flower buds are magenta; flowers open to magenta pink, lighter pink silver white when fully open. Very fragrant. Foliage green, tipped burgundy-bronze when young. Known to be hardy in USDA Zones 5 to 8. A standard portfolio has been opened at Royal Botanical Gardens Herbarium, Hamilton, Ontario, Canada, but is still incomplete. Literature reference: M.L. Peterschick. 2002. Lilacs Quart. J. 31(3):73.
Syringa L. Villosae Group was registered 30 Sept. 2003, by Ir M.H.A. (Marco) Hoffman, Applied Plant Research, Unit Nursery Stock, P.O. Box 118, 2770 AC Boskoop, The Netherlands. This group is based on the botanical series Villosae C.K. Schneider. Cultivars of the Villosae Group are shrubs with upright habit, 1.5 to $5 \mathrm{~m}$ high; leaves simple, entire, large, up to 10 to $25 \mathrm{~cm}$, oblong, elliptic to (ob)ovate, often with rough texture, glabrous or more or less hairy underneath; thyrses from a terminal bud, large, up to 15 to $40 \mathrm{~cm}$ long; corolla tube slender, longer than the lobes; flowering period relatively late. Syringa 'Royalty' has been designated nomenclatural standard for the Villosae Group. Examples of Villosae Group cultivars are 'Agnes Smith', 'Alice Rose Foster', 'Basia', 'Bellicent', 'Danusia', 'Donald Wyman', 'Esterka', 'Goplana', 'Hiawatha', 'Jagienka', 'James Macfarlane', 'Lynette', 'Minuet', 'Miss Canada', 'Nike', 'Nocturne', 'Redwine', and 'Royalty'. The suggested way of writing cultivar names is Genus (Group) 'Cultivar', e.g., Syringa (Villosae Group) 'Royalty'. Users have the choice of leaving out the Group, e.g., Syringa 'Royalty'. First published: M.H.A. Hoffman, Syringa Villosae Groep, sortimentsonderzoek en keuringsrapport. Dendroflora 39:104-119 (2002) (in Dutch, summaries in English and German), actual date of publication: September 2003; cultivar group name established and accepted.

Syringa vulgaris L. 'Lee Jewett Walker'. The cultivar name 'Lee Jewett Walker' was registered in 1978 [F. Vrugtman, AABGA Bul. 13(4):110; 1979]. There is convincing evidence that Kenneth Berdeen made an error when filling in the registration form in 1978, describing his selection 7-22 as having double and pink florets. The flowers are single and pink (S V). More detailed information can be found in F. Vrugtman, Lilacs Quart. J. 32(4):149 (2003) and 33(1):20 (2003).

All correspondence concerned with additional information or plants or propagules of newly registered lilac cultivars should be directed to the registrants listed below, not to the Registrar. Contribution 120, Royal Botanical Gardens, Hamilton, Ontario, Canada.

IInternational Registrar, International Cultivar Registration Authority Genus Syringa L. 